\title{
FREEDOM AND THE ROLE OF THE PRESS ON LAW ENFORCEMENT REVIEWED IN THE PERSPECTIVE OF LAW NUMBER: 40 OF 1999, CONGERNING THE PRESS
}

\author{
Satino ${ }^{1}$ \\ Yuliana Yuli $\mathbf{W}^{2 *}$ \\ Iswahyuni Adil ${ }^{3}$ \\ 1,2 3Veterans National Development University, Jakarta, Indonesia \\ e-mail: satino@upnvj.ac.id ${ }^{1}$,yuli@upnvj.ac.id ${ }^{2}$, iswahyuni@upnvj.ac.id ${ }^{3}$ \\ *Correspondence: yuli@upnvj.ac.id
}

Submitted:13 October 2021, Revised: 21 October 2021, Accepted: 27 October 2021

Abstract. Law Number 40 of 1999 concerning the Press is one of the legal regulations that have a role in efforts to realize a good life together. The struggle of the Indonesian press to achieve freedom was finally achieved after the enactment of Law Number 40 of 1999 concerning the Press. The purpose of this study is to find out how the freedom and role of the press in law enforcement are reviewed from the perspective of Law Number 40 of 1999, concerning the press. This study uses a sociological juridical method, the results of research conducted on real facts in society with the intent and purpose of finding facts, then proceeding with finding problems, ultimately leading to problem identification and leading to problem solving. The results of the research include the press trying to carry out its functions, rights, obligations, and roles, so the press must respect the human rights of everyone. The press has an important role in realizing Human Rights (HAM), as guaranteed in the Decree of the People's Consultative Assembly of the Republic of Indonesia Number: XVII/MPR/1998. Based on the results of the research above, it is necessary to uphold the freedom of the press in conveying public information in an honest and balanced manner and that freedom of the press is not absolute for the press alone, but to guarantee the rights of the public to obtain information. what happened in the context of realizing press freedom as contained in Law/040/1999 concerning the Press.

Keywords: freedom of the press; freedom of speech; law number 40 of 1999. 


\section{INTRODUCTION}

The growth and development of the national press has a relationship with each other, with the rate of growth and development of national development as a whole. We have experienced the rapid growth and development of information media in an up-to-date manner both from within the country and abroad (Nafiah, 2021).

As in the research (Jusrianto et al., 2019). it is explained that with newspapers, sometimes chaos appears, but without newspapers there will always be oppression, various information around us cannot be separated from publications such as the press, the word press is already familiar. again in social life to this day, almost all circles in the components of society, talking about the press means that we enter the scope of information. On the one hand, the press is one of the media that supports the success of development, on the other hand, the press has benefited a lot from the success of development (Jusrianto et al., 2019).

The term Press comes from the Dutch language which in English means Press. Literally press means print and literally means printed publication or printed publication (Sousa et al., 2016). The press is a necessity of life, and the press must be guided by the guidelines of the Press Law itself. Humans and law are 2 (two) things that cannot be separated in life in this world. This is because without laws that regulate human behavior there will be chaos in human life (society) (Manan, 2014).The innate nature of humans who want to always win alone and be selfish must be regulated and regulated in such a way by law without exception, so as not to violate the rights of others (Syaifullah, 2021).

The role of law is so important that the Indonesian people are further elaborated in Article paragraph (3) of the 1945 Constitution which states that the Indonesian state is a state of law. This means that all Indonesian citizens and government officials must act according to applicable law. Article 27 paragraph (1) of the 1945 Constitution also states that all citizens have the same position in law and government and are obliged to uphold the law and government without exception. Then Article 27 paragraph (1) of the 1945 Constitution states that the Indonesian state guarantees equality before the law (equality before the law without exception) in the life of the nation and state (Sujamawardi, 2018).

The press is a social institution and a vehicle for mass communication that carries out journalistic activities which include seeking, obtaining, possessing, storing, processing, and conveying information in the form of writing, sound, images, sounds, and images, as well as data and graphics as well as in other forms using media. print, electronic media, and all kinds of available channels (Akil, 2014). According to the statement (Khusna \& Susilowati, 2015) in the Big Indonesian Dictionary, the press is defined as:

1. Printing and Publishing Business.

2. Efforts to collect data and broadcast news.

3. News broadcasting through newspapers, magazines and radio.

4. People involved in news broadcasting. 
257 | Freedom and the Role of the Press on Law Enforcement Reviewed in the Perspective of Law Number: 40 of 1999, Concerning the Press

5. News broadcast media such as newspapers, magazines, and radio, television, and films.

Meanwhile, in the legal dictionary the press is defined as a business related to printing, publishing, journalism, news broadcasting in newspapers, radio magazines, films and television (Oktalavendri, 2016). As in the research (Iramdhan, 2019) provides an understanding of the press that can be viewed from a narrow sense and a broad sense, namely:

a. The press in a narrow sense contains in it the broadcasting of thoughts, ideas, or news through written words

b. -. In a broad sense, it includes all mass communication media that channel one's thoughts and feelings, both in written and spoken words.

As for the research (Berbahaya \& Simaputang, 2016), argues that the communication lexicon provides a similar definition of the press with the two definitions above as follows:

1. Printing business or publishing business

2. news gathering and broadcasting

3. News broadcasting through newspapers, magazines, and television The

press has another aspect, not just reflecting what happened reactively, postincident, post-fact, but seeing things first, planning and scheduling. The press doesn't just ride the news, but, say, just differentiates, makes news, plans news. From this point of view, it is argued that the press is not only carried away by events and problems, but rather creates, determines or more proportionally influences the agenda. The press is also defined as a collection of publications issued from the press, or publications that provide a person's sentiments and opinions through the print media. While Article 1 paragraph (1) of Law no. 40 of 1999 concerning the Press defines the "press" as a social institution and vehicle for mass communication that carries out journalistic activities, including seeking, obtaining, possessing, storing, processing, and conveying information in the form of writing, sound, images, sounds. and images, and data. and graphic and electronic media, and all available channels (Wardaya \& Komari, 2011).

\section{Press Principles}

1. Law no. 40 of 1999 concerning the Press

Based on Law no. 40 of 1999 concerning the Press, Article 2 (T. H. Lubis \& Koto, 2020), states that press freedom is a form of popular sovereignty based on the principles of democracy, justice and the rule of law.

a. The principle of democracy. The purpose of the principle of democracy is that the press must uphold democratic values by respecting and guaranteeing human rights and upholding the freedom to express thoughts/opinions, both orally and in writing.

b. The principle of justice, in the delivery of information to the public (the public) must uphold the value of justice. Where in the reporting does not take sides or submit to one party but must be balanced and not detrimental to either party (onesided).

c. The principle of the rule of law, the press in carrying out its activities 
must be based on law. Where to place the Law as the basis for action which is positioned at the highest level. So the press is not necessarily so free to act even though there is a guarantee of press freedom provided by law.

Article 2 of Law Number 40 of 1999 concerning the Press states that press freedom is a form of popular sovereignty based on the principles of democracy, justice and the rule of law. Democracy is a form or system of government in which everyone participates and governs through their representatives (government and people), ideas or views of life that prioritize equal rights and obligations and equal treatment for all citizens (Warren, 2018). Justice comes from the word fair, which means impartial, impartial. Justice is an attribute (action, treatment, etc.) Supremacy is defined as the highest power (over). So the rule of law, where the law is the highest power or the highest power, which is the legal umbrella, guidelines, and guidelines in compiling a news. Functions of the Press Article 3 of Law Number 40 of 1999 stipulates that the functions of the press are as follows:

a. The national press has a function as a medium of information, education, entertainment, and social control.

B. In addition to the functions as referred to in paragraph (1), the press functions as an economic institution.

Meanwhile, Kusumaningrat stated that the functions of the press are as follows:

1) Function

Informativelnformative function is the function of providing information through periodic news to the public. The press collects news that is considered useful and important for many people and then writes it down.

2) The Control function responsible Presswill definitely step back, investigating government or corporate work. The press must report what is going well and what is not.

\section{Restrictions on press freedom}

Before going into substance, it is necessary to clarify several things:

1. The term freedom of the press, not freedom of the press, in writing or speech, the two terms are used interchangeably, freedom is nothing but freedom, and vice versa, the term freedom of the press which is side by side with the term press freedom is more widely known to the public than the term press freedom. The term "freedom of the press" is more widely known to the public than the term "freedom of the press", especially when juxtaposed with freedom of the press or liberty of the press, besides that, normatively UU/040/99 uses the term freedom of the press.

2. The term "press" comes from the Dutch "press" and in English it is called "press" (freedom of the press). It literally means a printing press or a printing press because it is a print medium. We are familiar with the term press delict. Currently the term press is no longer limited to print media, but all public information media that meet journalistic requirements, journalistic codes as journalistic standards regulated by law or manual practice. press" now the term 
259 | Freedom and the Role of the Press on Law Enforcement Reviewed in the Perspective of Law Number: 40 of 1999, Concerning the Press

media is getting more and more prominent. New books in the field of the press use the term "media" more (media law, ethics and privacy of media and media, etc.). There are also books that still use the term press or the press (when the press fails, attacks on the press) today, in Indonesia it is more common to use the term "social media" rather than "social press". Apart from normative reasons (UU/040 (1999) the use of the term "press" has become a language that is very well known to the public, while the term "media" can still cause confusion such as "planting media". Iy to obtain information but more than that because the press can shape public opinion, which causes the press to play an important role in people's lives, the function of influencing newspapers is implied in editorials and articles

As an institution under the State in carrying out its functions as educators, information media, control social media and entertainment media. The press has provisions that regulate all actions and performance in the reporting process, including in carrying out its obligations and roles for the community (Wajong, 2018). All of its roles are contained in Law Number 40 of 1999 concerning the Press, Chapter II Article 6 with 5 paragraphs, namely: (1) Fulfilling the public's right to know; (2) Enforcing the basic values of democracy, encouraging the realization of the rule of law and human rights, and respecting diversity; (3) Develop public opinion based on precise, accurate and true information; (4) Supervising, criticizing, correcting, and suggesting matters relating to the public interest; (5) Fight for justice and truth.

Based on the results of the description above, that the author wishes to conduct a research with the title "Freedom and the Role of the Press in Law Enforcement Judging from the Perspective of Law Number: 40 of 1999, Concerning the Press".

\section{METHODS}

The method used is sociological juridical, this is the result of research conducted on real facts in society with the intent and purpose of finding facts, then proceeding with finding problems, ultimately leading to problem identification and ultimately leading to problem solving.

\section{RESULTS AND DISCUSSION}

\section{Legal Basis}

1. Press Law

There are five basic considerations for reforming the press law, which can be seen in the section on considerations of the law.

a. Freedom of the press is a form of people's sovereignty and is a very important element for realizing a democratic society, nation and state, so that the freedom to express thoughts and opinions as stated in Article 28 of the 1945 Constitution must be guaranteed. Press freedom is a means of fulfilling human rights to communicate and obtain information. In realizing press freedom, Indonesian journalists are aware of social responsibility and community diversity.

b. In the life of society, nation and 
democracy, freedom to express thoughts and opinions according to one's conscience and the right to obtain information are very essential human rights, which are needed to uphold justice and truth, promote public welfare, and educate the nation's life.

c. The national press as a vehicle for mass communication, information dissemination, and opinion formation must be able to carry out its principles, functions, rights, obligations and roles as well as possible based on professional press freedom, so that it must receive legal guarantees and protection, and be free from interference. and coercion from anywhere.

d. Because the national press plays a role in maintaining world order based on freedom, eternal peace and social justice.

e. Because the Old Press Law is no longer in accordance with the demands of the times.

In addition to the five basic considerations above, the General Elucidation of the Press Law mentions six main ideas formulated in the formation of the Press Law.

1) In order for the press to function optimally as mandated by Article 28 of the 1945 Constitution, it is necessary to enact a Press Law.

2) It is believed that in a democratic life accountability to the people is guaranteed, a transparent state administration system functions, and the realization of justice and truth.

3) It is understood that the press which has the freedom to seek and convey information is also very important to realize the Human Rights (HAM) guaranteed by the Decree (Tap) of the People's Consultative Assembly (MPR) No. XVII/MPR/1998 on Human Rights.

4) The press, which also exercises social control, is believed to be very important to prevent abuse of power, including corruption, collusion, nepotism (KKN), as well as other abuses and irregularities.

5) In carrying out its functions, rights, obligations and roles, the press respects the human rights of everyone, therefore a professional and open press is required to be controlled by the community.

6) To avoid overlapping arrangements, this Press Law does not regulate the provisions that have been regulated with the provisions of other laws and regulations.

In line with the five basic considerations and six main ideas for the formation of the Press Law above, at the end of April 2004 the Constitutional Commission (KK) agreed to include the protection of press freedom in the 1945 Constitution, and it will be regulated in Article 28 letter G (Japri \& Munawarah 2019). It was agreed that it would be included in Article 28 letter $\mathrm{G}$ of the 1945 Constitution, which states that the state protects press freedom and freedom of expression. Freedom of the press is part of human rights that must be recognized and protected in the constitution. This explicit mention is very important, and is intended so that the government or parliament that implements the constitution does not carelessly describe the protection of press 
261 | Freedom and the Role of the Press on Law Enforcement Reviewed in the Perspective of Law Number: 40 of 1999, Concerning the Press

freedom in accordance with the legal politics of the ruler at that time. Press) while the Constitutional Commission only approved at the end of April 2004 the inclusion of state protection for press freedom in the 1945 Constitution. The Press Law uses the term press freedom, and the Constitutional Commission uses the term press freedom. It can be concluded that there is actually no difference in principle between the terms press freedom and the terms press freedom. The term used normatively is press freedom, but in spoken language the term press freedom is preferred. Freedom of the Press is freedom of the press, and vice versa, freedom of the press is freedom of the press. Freedom of the press is guaranteed as a human right of citizens, is not subject to censorship, prohibition or prohibition of broadcasting, and as a guarantee of press freedom, the national press has the right to seek, obtain, and disseminate ideas and information. Freedom of the press will thus be expressly stated in Article 28 letter G of the 1945 Constitution, and in the Press Law.

\section{Journalistic Code of Ethics}

Freedom of opinion, expression and press are human rights protected by Pancasila, the 1945 Constitution, and the United Nations Universal Declaration of Human Rights. Freedom of the press is a means for the public to obtain information and communicate, in order to fulfill essential needs and improve the quality of human life. In realizing press freedom, Indonesian journalists are also aware of the interests of the nation, social responsibility, community pluralism, and religious norms. In carrying out its functions, rights, obligations, and roles, the press respects the human rights of everyone, therefore the press is required to be professional and open to be controlled by the public (Tumengkol, 2021).

In Article 7 number (2) of Law Number 40 of 1999 concerning the Press, it is explained that journalists have and obey the Journalistic Code of Ethics. Following up on this Journalistic Code of Ethics, the Press Council has issued Press Council Regulation Number 6/PeraturanDP/V/2008 concerning Ratification of Press Council Decree Number 03/SK-DP/III/2006 concerning Journalistic Code of Ethics. Ethics as a Press Council Regulation. In the attachment to the Press Council regulation it is stated:

Freedom of opinion, expression and press are human rights protected by Pancasila, the 1945 Constitution, and the United Nations Universal Declaration of Human Rights. Press freedom is a means for the public to obtain information and communicate, in order to fulfill essential needs and improve the quality of human life (Metalianda, 2017). Efforts to realize independence per situ, Indonesian journalists are also aware of the interests of the nation, social responsibility, community diversity and religious norms. In carrying out its functions, rights, obligations, and roles, the press respects the human rights of everyone, therefore the press is required to be professional and open to be controlled by the public. To guarantee press freedom and fulfill the public's right to obtain correct information, Indonesian journalists need a moral and professional ethical foundation as operational guidelines in maintaining public trust and 
upholding integrity and professionalism. On that basis, Indonesian journalists establish and comply with the Journalistic Code of Ethics (Eskens et al., 2017). Furthermore, Article 1 of the Journalistic Code of Ethics states that Indonesian journalists are independent, produce news that are accurate, balanced, and do not have bad intentions. The interpretation of this article explains:

a. Independent, means reporting events or facts in accordance with the voice of conscience without interference, coercion, and intervention from other parties, including the owner of the press company.

b. Accurate, meaning that the truth can be trusted, in accordance with the objective circumstances when the event occurred.

c. Balanced means that all parties have the same opportunity.

d. Has no bad intentions, meaning that there is no intentional intention to harm other parties.

\section{The Role of the Press in Law Enforcement}

To know the role of the press in law enforcement, several things must first be clarified, including:

a. Is there any interaction between the press and law enforcement?

B. If there is an interaction, what is the form of the interaction?

C. Are there any limitations in the interaction?

The answer to the question above is determined by two things:

a. The function of the press itself

b. Prerequisites for law enforcement to realize good, true, sure and fair implementation of the law.

Regarding the function of the press according to Law Number: UU/040/99 concerning the Press, it is distinguished between the function of the press, the function of information, the function of education, the function of entertainment, the function of supervision, and the function of supervision. Economic function (article 3). More generally, these functions can be classified into:

a. Information function, this function includes the function of conveying (spreading) information, and the function of receiving information

b. Political function, this function includes the function of control, both over power and in social relations (society) and the function of channeling, shaping and directing public opinion.

c. Economic function, this function places the press as a form of economic business, both for the economic interests of business actors (seeking profit), as well as for the economic interests of the community in general (providing employment or participating in corporate social responsibility).

d. Entertainment Function

To carry out this function, there are several characteristics inherent in the press.

1) ress is a public institution or social institution (social/public institution). This trait implies that although it is referred to as the fourth estate or fourth power, it is not a substructure of the state power organization (staatsorganisatie), and the press only works for and in favor of the public interest. Of course the 
263 | Freedom and the Role of the Press on Law Enforcement Reviewed in the Perspective of Law Number: 40 of 1999, Concerning the Press

organizers (organizations) of state power are also expected to work for the public interest.

2) The press must be free (independent) both in the sense of freedom and freedom of expression in general, freedom of opinion or expression. It should be noted that the most essential thing in freedom of opinion is freedom of opinion.

\section{Law enforcement}

Law arises because every society or group requires a certain way to resolve disputes between them. In addition, to enforce very basic norms in their lives. Friedman views, it is possible that every society needs certain mechanisms to change norms and apply them to new situations. In this sense it can be said that every group or society has a law. (Teubner, 2020).

Law enforcement is only one of the meanings of law, it can also be added, law enforcement will always be related to the process of formation and interpretation. Thus, every time an official enforces the law, he not only pays attention to the sound of the law but also relates to the process of forming the law to be applied, which will also include things such as reasons, background, formulation, objectives. and goals and so on. -Others that will lead to good and correct law enforcement.

\section{Press Relations and Law Enforcement}

Three Aspects of Press Relations and Law Enforcement

1. The press as an object of law enforcement or influenced by law enforcement. Law cannot be separated from society, and vice versa. So law and society are said to have a reciprocal relationship. Therefore, there is no aspect of human life in society that escapes the touch of the law. The press becomes the object of law enforcement because the press is a legal subject, the press as a legal subject can influence press actors (journalists, editors, press owners) or the press as an institution. including offenses of a criminal, administrative or administrative nature. Criminal offenses may include acts such as defamation, or defamation or invasion of privacy, trespassing, spreading state secrets. During the colonial period, we were known as "violations of the law" such as "acts of spreading (feeling) hostility towards authority (haatzai articlesen). Actually the above provisions apply to every legal subject, not only limited to the press.

2. The press as a facilitator of law enforcement, one of the One of the functions of the press as the oldest function is to provide or convey information to the public (news about murder, violence or abuse, traffic accidents, corruption, theft, fraud, building without permission, rights disputes, etc.), which is no less important is the function of the press. the press conveys information to the public about ongoing legal processes inside or outside the judicial process (such as arbitration) and (currently cases that are still hot, such as the Jesica case, and the drug case of Gatot/chairman Farfi).

3. The press as an obstacle law enforcement, we acknowledge the trial 
of expression by the press. This expression describes, through the press or In the rubric of public opinion, or press opinion itself, the press already has a legitimate public opinion or at least encourages the public to think about a case that has not been decided by the authorities (court or out of court). Reporting or conveying opinions of this kind not only violates the principle of presumption of innocence (harming the "losing" party and the alleged perpetrator of a crime, violating the principle of presumption of innocence), but is also a form of inhibiting justice, trial and impartiality, and even an insult to judicial order. Furthermore, it can be noted that all forms that can be classified as trial by the press, obstruction of justice, or contempt of court, with the intention of influencing the judge, constitute a violation of the principle of guaranteeing the independence of judges, fair trial, impartiality to decide a case correctly and appropriately and fair.

4. Freedom of the press and an independent judiciary (freedom of judges) Freedom (freedom) of the press in a society that longs for democracy, upholds human rights, and a society that longs for progress, is seen as a necessity. According to the American Press Commission, press freedom is essential to political freedom. When one cannot freely convey his thoughts to others, there is no guarantee of freedom. If there is freedom of expression, it means the beginning of a free society and it means there are all rights to freedom.

\section{Functions, obligations of the press and objectives of the press}

According to Law no. 40 of 1999 concerning the Press in (Z. I. Lubis, 2020), it is stated that the press is a social institution and a vehicle for mass communication that carries out journalistic activities. Including seeking, obtaining, possessing, storing, processing, and conveying information in the form of oral, written, sound, image or electronic media, and all available commercial channels. The National Press has a function as a medium of information, education, entertainment and social control. In addition to the functions as referred to in paragraph (1), the national press can function as an economic institution.

The dimension of idealism relates to the thoughts, ideas, and public or individual opinions that are owned or managed by the press. In this function there are three main levers of the press, namely: providing information, educating the public and entertaining or providing entertainment for its readers, these three tasks must be contained in the press, if only providing information the press will look dry, like vegetables without salt, even though it is nutritious (Hutomo, 2020). not good. Likewise, if the press only supports entertainment, it does not provide anything meaningful for the development of the reader's reasoning power. Normatively, the idealism function of the press is explained in press laws and regulations, as in $U U / 11 / 1966$ and $U U / 21 / 1982$ in article 2 paragraph (1) UU/11/1966 it is stated that the function of the press is as a revolutionary tool and is a media. mass that is active, dynamic, creative, informative, 
265 | Freedom and the Role of the Press on Law Enforcement Reviewed in the Perspective of Law Number: 40 of 1999, Concerning the Press

and has a social function, encouraging and

fostering progressive thinking and thinking, which includes all manifestations of the life of the Indonesian nation. Law/21/1982 article 2 paragraph (6) states that in order to increase its role in development, the press functions as an objective disseminator of information, a distributor of public aspirations, an expansion of objective information, a distributor of public aspirations, expansion of communication and public participation, and social control constructive. In this case, a positive interaction is needed between the government, the press and the community (Arswendi, 2017). The function of the press according to Law/40/1999 as referred to in Article 3 paragraphs (1) and (2) is that the national press functions as a medium of information, education, entertainment, social control, and as an economic medium. Institution As in Law/40/1999 it is expressly stated that the idealism and commercial function of the press is different from Law/11/1966 and Law/21/1982 which emphasizes the function of the press more than its idealistic content. The purpose of the press is to continue to be in the public eye for every consideration and decision taken by the government, because everything the government does must be done on behalf of the people (Bilardo, 2019). This constant scrutiny will no doubt put constant pressure on members of public office, but it is this pressure that makes their role as public representatives, fulfilling the public interest above their role as citizens and fulfilling private interests. Any action or change proposed by the government should be scrutinized and examined in detail.

\section{Responsibilities of the Press}

The function of Press Freedom in Indonesia is to provide space for the press community to express and express opinions. After the 1988 political reform, freedom of the press was opened as wide as possible in contrast to the New Order era, when press freedom was still pseudo, the press became one of the most influential forces in society, which was supported by a massive revolution in technology, the press was very easy and extraordinary. . spread the news quickly to all elements of society. The dream of practitioners or the world of the press to grasp and rule the world, can now become a reality. The press is very quick to calculate power, they are able to anticipate how the formation of opinion through reporting is carried out by the target community (Musman \& Mulyadi, 2017), then calculate the political and financial impact they will receive. The press and media practitioners cleverly read the opportunity to convince all elements that it was now the turn of the press and other mass media to take the throne. The power and power of mass media in society makes it something that everyone should be reckoned with. Unlike the previous times (colonial era, guided democracy (old order), and the new order), the press and other mass media have experienced independence and freedom in the true sense, no longer artificial.

\section{Responsibilities of the Press According to Legislations and Journalistic Codes of Ethics}

The balance of press freedom is the 
responsibility in carrying out its functions (Saputra, 2018), obligations, rights and roles of the press, as stated in Article 5 UU/11/1966 which was amended and refined by Law /04/1967 and UU/21/1992 articles 2, 3, 4 and 5 . The function of the obligations and rights of the press, in UU/11/1966 article 2 ( 1 ) it is stated that the national press is a revolutionary tool and is a mass media, relatively active, dynamic, creative, informative, and social. movers and cultivators of critical and progressive thinking cover all manifestations of the life of the Indonesian nation. The obligations of the national press article 2 (2) of Law Number 11 of 1966 are as follows:

1. Defend, defend, support and implement Pancasila and the 1945 Constitution in a pure and consistent manner.

2. Fight for the implementation of the mandate of the suffering of the people based on Pancasila democracy.

3. Struggle for truth and justice on the basis of press freedom.

4. Fostering unity and revolutionary progressive forces and struggles against imperialism, colonialism, neocolonialism, feudalism, liberalism, communism and fascism/dictatorship.

5. to be a conduit of constructive and progressive revolutionary public opinion.

Article 3 of Law/11/1966 explains that the press has the right to corrective and constructive control, criticism and correction. Since the enactment of Law/11/1966 above, the press is required to be a motivator in the intellectual life of the nation. The press in this case has an educative function, although in the past it was a point of pressure, the press is still allowed to always use its rights, namely the right to control, criticize, and correct. In this case, the press can become the power of balance in the midst of a passionate struggle against imperialism, colonialism, neocolonialism, feudalism, liberalism, communism and fascism/dictatorship.

\section{The Legal Basis Of The Indonesian Press}

The reform era became the era of press freedom. Compared to the New Order era under the shackled leadership of President Suharto, press freedom is now often considered too much. But unfortunately, the freedom of the press has not been accompanied by guarantees of safety and protection for the journalistic profession (Teguh, 2021). Every citizen basically has the right to get legal protection. One of the most basic rights possessed by humans is regulated in the 1945 Constitution of the Republic of Indonesia as the highest legal basis in Indonesia.

\section{Article 28 of the 1945 Constitution}

Freedom of association and assembly, expressing thoughts and oral and written, and so on is stipulated by law.

Article $28 \mathrm{~F}$ of the 1945 Constitution

Everyone has the right to communicate and obtain information to develop their personal and social environment, as well as the right to seek, obtain, possess, store, process, and convey information using all available channels.

MPR Decree Number: XII/MPR/1998 concerning Human Rights

More details are found in the Human Rights Charter, Chapter VI, Articles 20 and 21 which reads as follows:

1. (20) Twenty, everyone has the right to 
267 | Freedom and the Role of the Press on Law Enforcement Reviewed in the Perspective of Law Number: 40 of 1999, Concerning the Press

communicate and obtain information to develop his personal and social environment.

2. (21) Twenty each person has the right to seek, obtain, possess, store, process and convey information by using all types of available means.

Law Number: 39 of 2000 article 14 paragraphs 1 and 2 concerning Human Rights:

1. Everyone has the right to communicate and obtain information needed to develop their personal and social environment.

2. Everyone has the right to seek, obtain, possess, store, process and convey information by using all types of available means.

Law Number: 40 of 1999 in article 2 and article 4 paragraph 1 concerning the Press:

1. Article 2 reads, Freedom of the press is a form of people's sovereignty based on the principles of democracy, justice, and the rule of law.

2. Article 4 paragraph 1 reads, Freedom of the press is guaranteed as a human right of citizens.

The current regulation on the press (Law Number 40 of 1999 was promulgated on 23 September 1999 was contained in the State Lebaran of the Republic of Indonesia of 1999 No. 166) contains various fundamental changes to the previous press law. This is intended so that the press can function optimally as mandated by Article 28 of the 1945 Constitution. This maximum function is needed because press freedom is an embodiment of people's sovereignty and is an important element in the life of a democratic society, nation and state. The old law which was replaced by a new law
(UU/040/99), essentially reflected the differences in the basic political ideological values between the New Order and the Reformation Order. This is clearly seen in the preamble to the new press law, which includes, among other things, that the old law on the provisions of the press center is deemed no longer in line with the demands of the times. In addition, regarding the functions, obligations, and rights of the press in the new law (UU/040/1999) it is no longer associated with the core appreciation and experience of P4 (Guidelines for the Implementation and Experience of Pancasila), the press must respect the human rights of every person. Therefore, the press is demanded by the community, among others, that everyone is guaranteed the right to answer and the right to correction. The press has an important role in realizing Human Rights (HAM) (Japri \& Munawarah, 2019), as guaranteed in the Decree of the People's Consultative Assembly of the Republic of Indonesia Number: XVII/MPR/1998 which among others, which states that everyone has the right to communicate and obtain information in line with the United Nations Charter on human rights. Furthermore, Article 19 reads, everyone has the right to freedom of opinion and expression, this includes freedom to hold opinions without interference, and to seek, receive, convey information and ideas through any media regardless of territorial boundaries. social control (social control) to prevent the abuse of power either corruption, collusion, nepotism, as well as fraud, irregularities and others. 


\section{CONCLUSIONS}

The press is the fourth pillar of democracy after the executive, legislature and judiciary, the press is the control over the three pillars and underlies its performance with checks and balances. To be able to perform its role, it is necessary to uphold the freedom of the press in conveying public information in an honest and balanced manner. Besides that, to uphold this fourth pillar, the press must also be free from capitalism and politics. press which does not only support the interests of capital owners and perpetuate political power without considering the interests of the larger community, and has been contained in the attachment to the Press Council Regulation Number: 5/Peraturan-DP/IV/2008 concerning the Protection of the Journalist Profession. Because freedom of the press is not absolute for the press alone, but to guarantee the rights of the public to obtain information, in practice there are still obstacles that occur in the context of realizing press freedom as contained in Law/040/1999 concerning the Press. Freedom of expression based on article 28 of the 1945 Constitution, freedom of the press in Indonesia is currently regulated in Law/040/1999 which in the contents of the article is guided by article 28 of the 1945 Constitution, but in practice there are still many obstacles to achieving appropriate press freedom. with UU/040/99, these obstacles can come from the community, the government and even from the elements of the press itself. After the enactment of Law/040/1999 concerning the Press, it did not only have a positive influence on the national press, and it turned out that this Law also had a negative influence on the basis of uncontrolled freedom and tended to be excessive.

\section{REFERENCES}

Akil, M. A. (2014). Media regulation in Indonesia. Jurnal Dakwah Tabligh, 15(2), 137-145.

Arswendi, R. (2017). Media, Simultaneous Pilkada and Democracy. Jurnal Transformative, 3(2), 31-41.

Berbahaya, Z., \& Simaputang, D. W. S. (2016). Perlindungan Keselamatan Kerja Bagi Reporter PT. Rajawali Televisi (RTV) Yang Bertugas Pada Lokasi.

BILARDO, T. (2019). Libertarian Press. Network Media, 2(1). https://doi.org/10.46576/jnm.v2i1.446

Eskens, S., Helberger, N., \& Moeller, J. (2017). Challenged by news personalisation: five perspectives on the right to receive information. Journal of Media Law, 9(2), 259-284. https://doi.org/10.1080/17577632.201 $\underline{7.1387353}$

Hutomo, M. S. (2020). Introduction to Social Responsibility Theory of the Press. Jurnal Ilmiah Indonesia.

Iramdhan, I. (2019). The History of the Development of the Press in Indonesia in terms of Education. Jurnal Ilmiah Wahana Pendidikan, 5(3), 53-65. https://doi.org/10.5281/jiwp.v5i3.113

Japri, M., \& Munawarah, I. Y. (2019). Press Freedom in Indonesia. Collegium Studiosum Journal, 2(1), 18-34. 
269 | Freedom and the Role of the Press on Law Enforcement Reviewed in the Perspective of Law Number: 40 of 1999, Concerning the Press

Jusrianto, J., Yunus, M., \& Parubang, D. P. (2019). Implementation of Law Number 40 of 1999 concerning the Role of the Press in Palopo Pos. Cura Animarum, 1(1), 35-44.

Khusna, I. H., \& Susilowati, N. (2015). Media Regulation in Indonesia: A Study on Public Information Disclosure and Broadcasting. E-Journal Universitas 17 Agustus 1945 Jakarta (UTA'45), 92-104. https://doi.org/10.52447/promedia.v1i $\underline{2.111}$

Lubis, T. H., \& Koto, I. (2020). Discourse on the Truth of News Based on Law Number 40 of 1999 concerning the Press and Journalistic Code of Ethics. $D E$ LEGA LATA: Jurnal Ilmu Hukum, 5(2), 231-250.

http://dx.doi.org/10.30596\%2Fdll.v5i2. $\underline{4169}$

Lubis, Z. I. (2020). Qualitative Analysis of the Use of Telemedicine as a Health Service Solution in Indonesia during the COVID-19 Pandemic. Physiotherapy and Health Science-PhysioHS, 2(2).

Manan, A. (2014). The role of law in economic development. Kencana Prenada Media Group.

Metalianda, M. (2017). Freedom of the Press in Legal Perspective in Indonesia. The Juris, 1(1), 71-86.

Musman, A., \& Mulyadi, N. (2017). Basic Journalism: A Practical Guide for Journalists. Anak Hebat Indonesia.

Nafiah, N. (2021). History and development of the press in Cirebon in the years 18901945. IAIN Syekh Nurjati Cirebon.

Oktalavendri, Y. (2016). Analisis Wacana Lirik Lagu "Merah" Karya Band Efek
Rumah Kaca. Perpustakaan.

Saputra, A. (2018). PWI (Indonesian Journalists Association) Makassar Gait Against Press Freedom in Makassar (1974-1998). Universitas Negeri Makassar.

Sousa, A. G. P., de Sousa Cabral, J. V., ElFeghaly, W. B., de Sousa, L. S., \& Nunes, A. B. (2016). Hyporeninemic hypoaldosteronism and diabetes mellitus: pathophysiology assumptions, clinical aspects and implications for management. World Journal of Diabetes, $\quad 7(5), \quad 101$. https://dx.doi.org/10.4239\%2Fwjd.v7.i5 .101

Sujamawardi, L. H. (2018). Juridical Analysis Article 27 paragraph (1) of Law Number 19 of 2016 concerning Amendments to Law Number 11 of 2008 concerning Information and Electronic Transactions. Dialogia luridica: Jurnal Hukum Bisnis Dan Investasi, 9(2). https://doi.org/10.28932/di.v9i2.974

Syaifullah, A. (2021). Legal Protection Against Funder Losses in Peer to Peer Lending-Based Financial Technology Transactions (Case Study of PT Alami Sharia). Fakultas Syariah dan Hukum Universitas Islam Negeri Syarif Hidayatullah Jakarta.

Teguh, P. P. (2021). Implementation of Law Enforcement Policies on Legal Cases Related to Press Reporting in Indonesia. Ilmu Dan Budaya, 42(73). http://dx.doi.org/10.47313/jib.v42i1.11 $\underline{64}$

Teubner, G. (2020). Dilemmas of law in the welfare state. de Gruyter.

Tumengkol, A. E. A. (2021). The Journalistic 
Code Of Ethics And Professionalism Of The Media. Jurnal Ilmiah Komunikasi Communique, 3(2), 37-49. https://doi.org/10.31289/jikq.v3i2.47

Wajong, P. B. (2018). Legal Protection for Journalists in Carrying Out Duties and Functions Related to Press Freedom according to Law Number 40 of 1999. Lex Et Societatis, 6(2). https://doi.org/10.35796/les.v6i2.1995 $\underline{4}$

Warren, M. (2018). Trust and democracy. The Oxford Handbook of Social and Political Trust, 75-94.

(c) (7) (2) $(02021$ by the authors. Submitted for under the terms and conditions of the Creative Commons Attribution (CC BY SA) license (https://creativecommons.org/licenses/by-sa/4.0/). 